\title{
The TRIS Project and the Socio-educational Inclusion of Homebound Students
}

\author{
Vincenza Benigno, Giovanni Caruso, Chiara Fante, Fabrizio Ravicchio, Guglielmo Trentin \\ Institute for Educational Technology, National Research Council, Italy
}

\begin{abstract}
The spread of network and mobile technologies offers new dimensions for interpersonal interaction and for "spaces" in which this can take place. The "always-on" status has in fact blurred the clear-cut distinction between physical and digital spaces, introducing a new conception of space, known as "hybrid" space. Hybrid spaces are dynamic spaces generated by constant connectivity, which transparently integrates remote contexts into those we are actually experiencing at that moment.

Thus the concept of "hybrid space" is clearly particularly interesting for those having to tackle daily the problem of social/educational inclusion, especially of students who are "homebound" because of physical and/or health problems.

And it is precisely the concept of the hybrid learning space that the TRIS project is focussed on, its aim being educational inclusion of students who have difficulty in attending school regularly due to specific invalidating illnesses.

One of the main results which emerged from the research is that teaching/learning situations which are developed in hybrid learning spaces due to the above force of circumstance, may also act as incubators of general educational innovation for the class/school, fostering experimentations in the didactic use of network and mobile technologies which can also be used as models for "normal" teaching.
\end{abstract}

\section{Introduction}

Physical or health problems often prevent students from participating in normal education, sometimes permanently [1][2].

For these students, new models of schooling based on the regular and methodical use of the new information and communication technologies need to be worked out [3][4][5] in order to improve (a) the management of the teaching/learning process [6] and (b) the communication among the subjects who are in contact with the disadvantaged students (teachers, classmates, parents, health workers) and also among the teachers who will be following their studies over the various school years [7].

Thus the variables of the problem need to be examined scientifically and experimentally in order to define a sustainable model of inclusive education which takes into account both the student's status, and the role of the social networks (Figure 1) involving him/her [8].

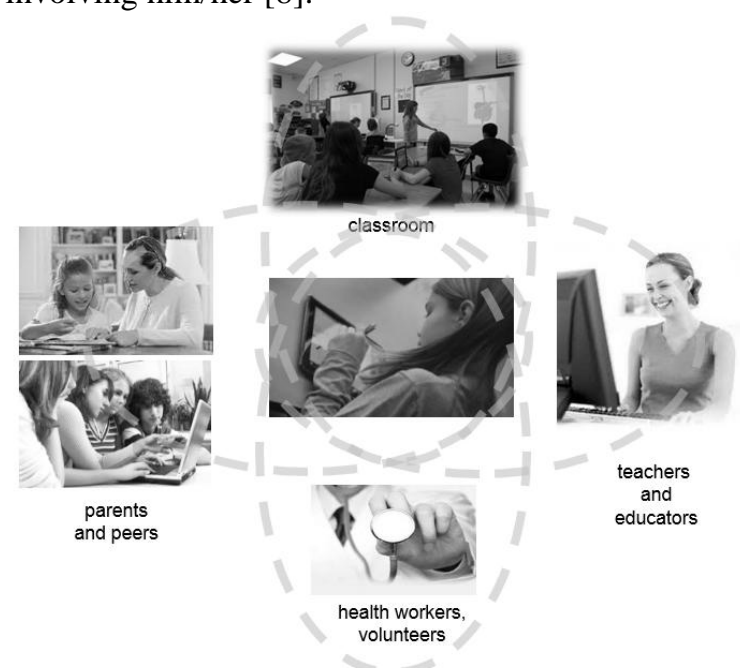

Figure 1. The complex of social networks involving the student

\section{The TRIS project}

In 2013, an important three-year framework agreement was signed between the MIUR (Italian Ministry of University and Research), the National Research Council and the Telecom Italia (telephone company) Foundation, for promotion of an experiment on the educational inclusion of students who have difficulty in attending school regularly due to specific invalidating illnesses.

The aim of the agreement is to try out new educational models for students who are either temporarily or permanently unable to follow normal educational paths due to psycho-physical problems, 
long-term hospitalisation, special treatment programmes (e.g. multiple chemical sensitivity), or particularly disadvantaged geographical situations (e.g. students residing on small islands or in mountain areas).

The operational development of the framework agreement is the TRIS (Tecnologie di Rete e Inclusione Socio-educativa - Network Technologies and Socio-educational Inclusion) project, coordinated by the Institute for Educational Technology of the Italian National Research Council (ITD-CNR).

\subsection{Aims and objectives of the project}

The aims of the project regard two levels, that of the student and that of the social networks dedicated to him/her.

In the former (student's) level, the specific aims regard (a) the acceptance and full insertion of the homebound student into class social life (social inclusion) [9], and (b) the working out of collaborative learning methods by which the student can be actively involved in the lessons and the study with his/her peers (educational inclusion), despite being based at home.

On the social network level, the project aims at strengthening self-help dynamics among all those directly and indirectly involved in the socioeducational inclusion of the disadvantaged students (teachers, parents, friends, volunteers, social workers), by exploiting network and mobile technologies (NMTs). Advantage is also taken of the connection to the extra-scholastic educational resources of the territory and of the mutual/informal learning processes within the online community (trainers, researchers, sociologists, social-cultural workers), whose purpose is the sharing of knowledge and good practices on socio-educational inclusion themes. The project involves 4 Comprehensive Institutes (Primary School and Lower Secondary School) and 3 Upper Secondary Schools of the Campania, Lazio, Sardinia and Sicily Regions.

A three-year duration was decided on for the project, to allow the experimentation to be conducted both within the single two/three-year study cycle and also straddling two cycles, i.e. the last years of one and at least the first year of the next. This was calculated to facilitate the transition between the endof-course teaching board and the following beginning-of-course one, with a harmonious transfer of methods.

\subsection{Main action lines of the project}

Methodologically speaking, the research develops along three closely complementary main action lines: (a) the study and experimentation of educational-methodological approaches aimed at socio-educational inclusion and centred on the use of a hybrid learning space [10][11]; (b) the study and experimentation of sustainable technological settings for application of the aforesaid educationalmethodological approaches; (c) the planning and experimentation of teacher training actions regarding designing, application and assessment of inclusive activities.

\subsection{The hybrid spaces in which the research developed}

The term BYOD (Bring Your Own Device) [12] in education indicates that nowadays students and teachers more and more frequently use their own personal devices for teaching and learning, during the lessons, or for studying alone or in groups.

The concept of BYOD thus originates in the mass spread of mobile devices. Besides being part of our daily lives, these devices amplify (a) the dynamicity of interactions among people and with online resources, and (b) the spaces in which these take place.

This situation moreover tends to make the line separating physical spaces (e.g. the classroom) from digital spaces (e.g. online learning environments) increasingly less clear-cut, leading to a new view of the space of interaction, which we might define as "hybrid".

Hybrid spaces are dynamic spaces created by the constant movement of users carrying portable devices which are continuously connected to the Internet and to other users.

This "always-on" status transforms our perception of space to include contexts which are remote from those we are actually living in at that moment. In this sense, a hybrid space is conceptually different from what we call mixed reality, enhanced reality or virtual reality [10].

In this radical change of scenario, learning spaces too can thus take on hybrid connotations (Figure 2).

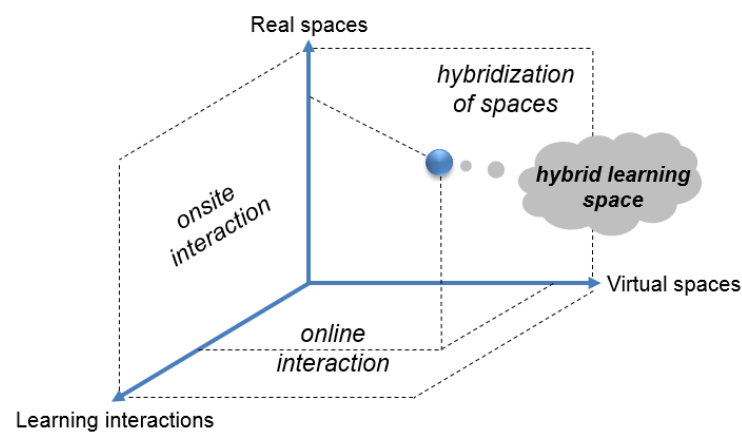

Figure 2. A conceptual representation of a hybrid learning space

The potential of hybrid learning spaces (HLS) is considerable. However, to be able to exploit them to the full, an adequate pedagogical scheme must be 
conceived and applied to them [11]. This scheme should foster radical didactic innovation.

This is a crucial step if we wish to ensure that the innovation is not only technological (because there is a personal use of network and mobile technologies $\mathrm{NMTs}^{1}$ ) but also, and above all, didacticmethodological.

The concept of "learning hybrid space" is thus seen to be particularly interesting for those daily tackling the problem of the socio-educational inclusion of students who are homebound due to physical, health or other problems [13].

\subsection{Monitoring system for the experimental activities}

A monitoring system was created for the project, whereby data and information were collected to evaluate the progress of the experimental activities and the methodological and technological results achieved. A diagram of its structure is shown in Figure 3.

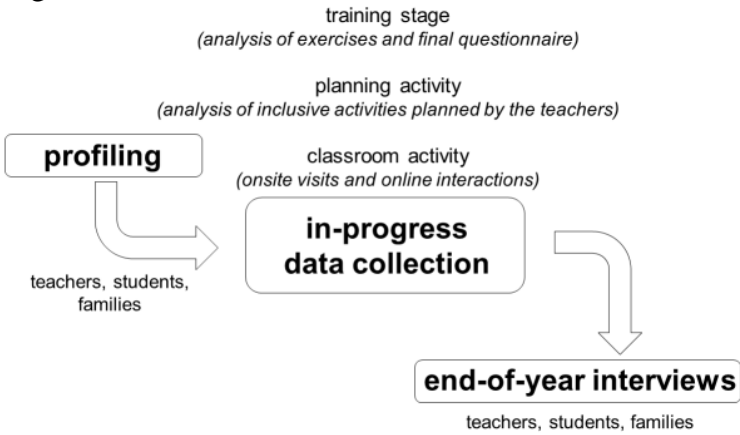

Figure 3. Development of the monitoring activity for one year of the project

\section{The study of inclusive educational approaches}

One of the main aims of the project is to work out educational-methodological solutions which are sustainable, i.e. specifically functional to the socioeducational inclusion of the homebound student and at the same time in harmony with the class teachers' teaching style. Thus, for each experimental stage we based ourselves on the synergic, complementary action of a broadly-based research-action group, i.e. a group which included both the ITD-CNR researchers and the teachers involved in the project.

In order not to weigh too heavily on everyday teaching and learning, and to guarantee the repeatability and sustainability of the solutions studied and experimented, it was decided, with the teachers, to adopt an approach which would intrude

\footnotetext{
${ }^{1}$ In this article, the term NMT is used in a fairly broad sense, incorporating both communication technologies and web resources which can be used through them (e.g. cloud, social media, instant messaging, apps for collaborative work etc.).
}

as little as possible on normal didactic process. The following basic principles were thus applied:

- co-planning of didactic activities through close collaboration between ITD-CNR researchers and teachers;

- constant online (and sometimes onsite) support from ITD-CNR researchers for experimenting teachers in the application stages;

- collaboration of teachers in collecting the information necessary for assessing the chosen solutions and the general progress of the project.

In planning the activities, we thus tried to ensure that they were not simply a superfluous and burdensome extension of those already scheduled by the teachers. At the same time we tried to stimulate in the teachers a wider reflection as to how the most commonly-used technologies (mobiles, tablets and smartphones) might be exploited to potentiate the day-to-day learning of the whole class, quite apart from the demands of the specific, disadvantaged situation. This is in accordance with the BOYD approach, which is based on students' and teachers' personal devices rather than on technologies present at school.

As we will see later, teachers were offered an introductory training course on the methodologies for planning experimental activities, to guarantee their effective operational insertion into the researchaction process.

\section{The study of technological settings}

The second action line of the project was the identification of a minimum set of technologies and online resources for creating a HLS within which the educational processes actively involving the nonattending student can be conducted, both during lessons and school activities and during homework or extra-school study (Figure 4) [14].

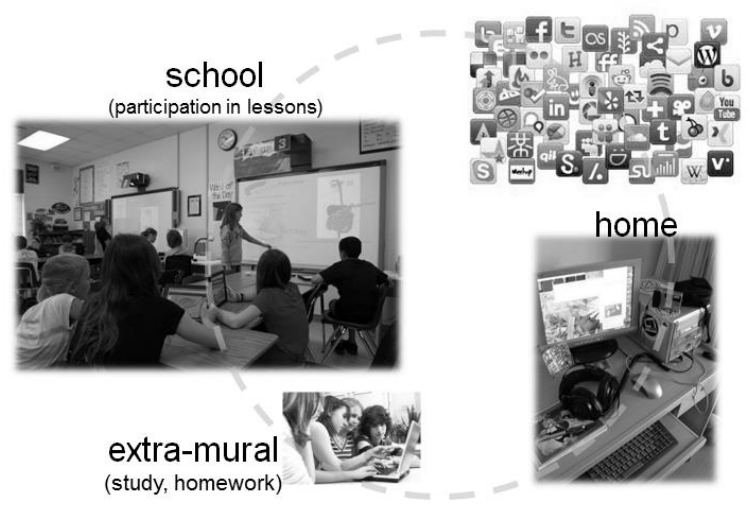

Figure 4. A full-spectrum process of socio-educational inclusion

Again with a view to sustainability, in both identifying and installing the technological settings (home side and classroom/school side), we tended to 
choose hardware and software solutions which are already widely used both at school and at home, espousing the BYOD approach [15][16].

This reproduced the typical situation in which a school more or less suddenly finds itself dealing with a student who has a situation of prolonged disadvantage and who needs to be involved in the lessons and study activities with his/her classmates. Since this situation is unrelated to any specific funded project, it needs to be able to count on technology which is already available in class and at home.

For this reason, in the initial stages of the experimentation we carried out an inventory of the tools already available to teachers, students and parents and of their habits regarding NMT use, as far as possible adapting the chosen solutions to these considerations.

Since TRIS can count on ad hoc funding from the Telecom Italia Foundation, all the experimental situations were equipped with identical technological kits, which always however complied with the basic decision to use only technology which everyone can afford.

The aim in providing equal instrumentation for all the different situations was:

- to integrate any incomplete technology at school/home in order to ensure that all the situations could operate under the same conditions;

- to verify how far it was possible to go in terms of methodological solutions, using those selected tools.

The minimum equipment guaranteed for each experimental situation consists of two parts, as shown in Table 1.

Table 1. Technological equipment provided in class and at home

\begin{tabular}{|l|l|}
\hline Class equipment & Home equipment \\
\hline Interactive White Board & LapTop computer \\
\hline LapTop computer & Tablet \\
\hline Tablet & Audio Kit \\
\hline Audio Kit Bluetooth & Printer/Scanner \\
\hline PTZ Webcam & Graphic Tablet \\
\hline Printer/Scanner & Wi-Fi mobile router \\
\hline
\end{tabular}

In order to use the above technological settings efficiently, the next step was to select some online services which would be able to enact the experimental activities planned by researchers and teachers. Two key elements were taken into account in this choice:

- the needs of communication, sharing and collaboration which are specific to educational inclusion;

- the use of free-of-charge, widely-used online services.
The online services indicated in Table 2 are those chosen for the initial teacher training. Actually, during the various experimentations, other services were added in accordance with the spontaneous evolution of activities for the homebound student's social/educational inclusion.

Table 2. Online services used for creating the hybrid learning space

\begin{tabular}{|l|l|}
\hline Service & Type of use \\
\hline Skype & Audio-video communication \\
\hline Telegram & Rapid messaging \\
\hline Skype+Google Drive & Co-construction of artifact \\
\hline Moodle & $\begin{array}{l}\text { Classroom Management Virtual } \\
\text { Space }\end{array}$ \\
\hline
\end{tabular}

\section{Teacher training}

The third main action line of the experimentation is teacher training. Besides being a further means for increasing the sustainability of the methodological solutions adopted, teacher training is a vital stage for actively involving teachers in the experimental activities.

The main aim of the training is in fact to bring about a kind of conceptual levelling as regards the research methods and tools proposed in TRIS, seeking to optimise the dialogue between teachers and researchers during the planning and carrying out of the research-action activities.

Thus, the training course was conceived as an ongoing process, i.e. a process which can accompany the teachers throughout their participation in TRIS.

After an initial (formal) basic training stage lasting 5 weeks and conducted wholly online, the course proceeds in the learning-on-the-job mode (informal learning mode), addressing teachers' specific needs for training in new technologies and seeking new educational solutions for the inclusion of their non-attending students.

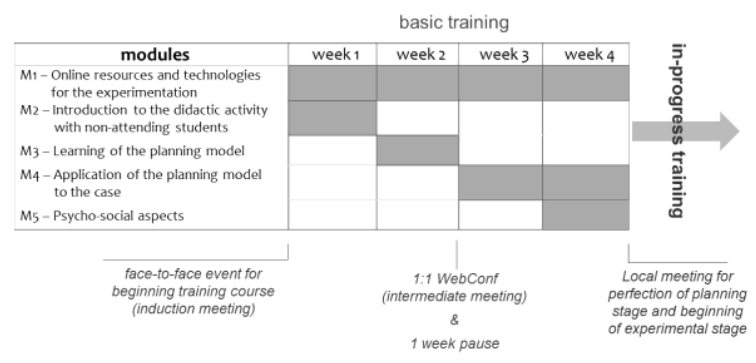

Figure 5. Development of teacher training in a formal/ non-formal/informal continuum

\section{First results achieved}

Although the project is at stage $2 / 3$, it has already produced important results [13].

From the educational/pedagogical point of view, the model of analysis of both the students' difficulties and the family context was found to be 
particularly effective in planning the (individual and group) study activities which can really be potentiated by NMTs. On the other hand, the planning of activities for training teachers to use network technologies and resources to support the teaching/learning process in a more decisive and widespread way still needs to be perfected, in the sense of simplified.

On the whole, however, the most important result is undoubtedly the chance given to homebound students to interrupt their isolation and participate with more continuity in class life, both inside and outside school times. This result also depends on a more regular use of both synchronous communication, for active participation in the lessons, and asynchronous communication, in study and assignments. In the first case (active participation in lessons) the standard solution adopted is the one shown in Figure 6.

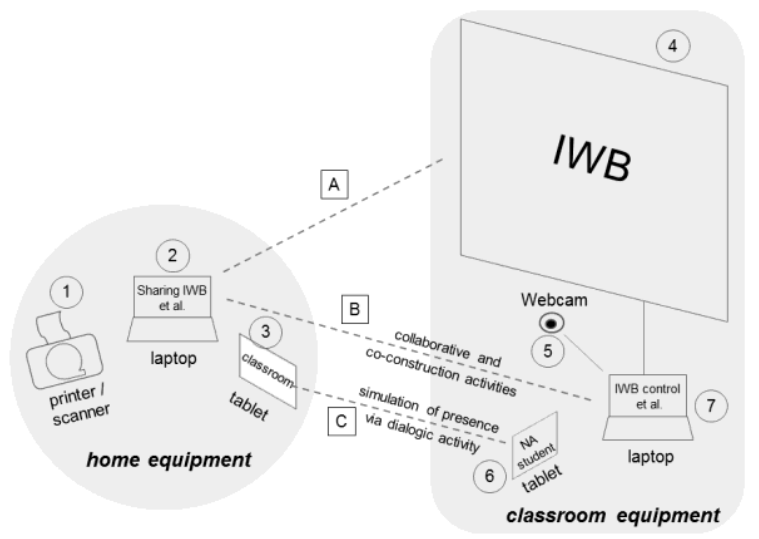

Figure 6. Technological settings for active involvement of the homebound student

Table 3 shows some situations using technological tools which, coupled with specific online services, served to create the desired HLS.

As can be seen in Figure 6, classroom equipment includes a PTZ webcam (5), so that the student at home can independently vary the angle of the class image, without depending on classmates or teacher.

Moreover it is interesting to note that the class tablet (6) was also used on school trips (e.g. museum visits) or in laboratory activities to allow the distance classmate to participate in the group, at least virtually.

Regarding the collaborative work inside and outside school time, a virtual reference space was worked out using (a) Moodle as the Learning Management System and (b) Google Drive tools for the collaborative homework exercises and construction of specific artefacts.

Finally, regarding the training course proposed to the teachers, a very positive reaction was recorded to the general approach adopted (online learning followed by situational learning-on-the-job).
The participants, who had generally been used to total solitude in their attempt to apply what had been learned in a training course, greatly appreciated the chance to get support from the ITD-CNR researchers, both during the online participation in the initial basic course and during the first experience of applying what they had learnt. But above all they appreciated the chance to continue learning in informal mode during the active, proactive participation in the research-action part of the project.

\section{Table 3. Examples of the use of the selected technological tools}

\begin{tabular}{|c|c|c|}
\hline A & $\begin{array}{l}\text { Use of home laptop for } \\
\text { sharing IWB (Interactive } \\
\text { White Board) screen } \\
\text { (and for collaborative } \\
\text { interaction with the } \\
\text { class. }\end{array}$ & $\begin{array}{l}\text { Typical situation: while } \\
\text { teacher and/or classmates act } \\
\text { locally on the IWB (4), the } \\
\text { student does the same at } \\
\text { home using his/her own } \\
\text { laptop (2). }\end{array}$ \\
\hline B & $\begin{array}{l}\text { Use of home laptop for } \\
\text { collaborative work with } \\
\text { a group of classmates. }\end{array}$ & $\begin{array}{l}\text { Typical situation: the class is } \\
\text { divided into small work } \\
\text { groups who are asked to } \\
\text { develop a document (a text, a } \\
\text { wiki, a conceptual map etc.); } \\
\text { the homebound student is } \\
\text { assigned to one of the } \\
\text { groups; the local group uses } \\
\text { the class laptop (7) to interact } \\
\text { collaboratively with the } \\
\text { homebound classmate, who } \\
\text { participates in the group } \\
\text { work with his/her own laptop } \\
\text { (2). }\end{array}$ \\
\hline $\mathrm{C}$ & $\begin{array}{l}\text { Use of tablets to simulate } \\
\text { the presence of the } \\
\text { student in the classroom } \\
\text { and at the same time to } \\
\text { open up a window onto } \\
\text { the class which is visible } \\
\text { from home. }\end{array}$ & $\begin{array}{l}\text { Typical situation: the tablet } \\
\text { (3) acts as a window onto the } \\
\text { class and at the same time } \\
\text { shows (if he/she wishes) the } \\
\text { student at home; the tablet } \\
\text { (6) reproduces the image of } \\
\text { the student at home (if he/she } \\
\text { wishes) and at the same time } \\
\text { shows what is happening in } \\
\text { the classroom (e.g. teacher's } \\
\text { lesson) }\end{array}$ \\
\hline
\end{tabular}

Reported below are some of the teachers' observations on the training programme, collected by means of a questionnaire administered at the end of the basic course.

"It is an innovative, interesting approach which is different from any other training course I have done so far."

"I liked the approach because it considers the human side, is supportive for participants, teaches knowledge and skills which are valid in the pedagogic field and encourages collaborative attitudes."

"It offered a moment of important reflection on aspects of teaching which are sometimes taken for granted."

"It has undoubtedly refined my perception of non-attending students and sensitivity towards them, helping me finally to "feel" them as an integral, and integrating, part of the class." 
"I would also recommend it to those who have not got the "urgent" situation of a non-attending student, because its approach really helps you teach in a way which considers and meets individual needs."

"Like all activities involving an approach to something new, it keeps the mind agile, arouses curiosity and helps to stop you falling into a routine, a risk which is common to all professions."

"It gives you the chance to reconsider your overall approach to teaching and emphasises the need to update your method to match the characteristics and needs of modern-day students."

Table 4. Summary of the responses divided into the different fields

\begin{tabular}{|c|c|}
\hline Field & Summary of responses \\
\hline Methodological & $\begin{array}{l}\text { - Acquisition of a more modern way of } \\
\text { teaching which is more interesting for } \\
\text { the class } \\
\text { - Re-interpretation of teaching } \\
\text { methodologies from another angle }\end{array}$ \\
\hline Technological & $\begin{array}{l}\text { - Ability to explore and "take chances" } \\
\text { with technological resources } \\
\text { - Increased confidence in the use of } \\
\text { technologies }\end{array}$ \\
\hline $\begin{array}{l}\text { Cognitive and } \\
\text { metacognitive }\end{array}$ & $\begin{array}{l}\text { - Development of greater awareness of all } \\
\text { aspects of the solution to a problem } \\
\text { - Acquisition of a more critical view of } \\
\text { one's way of working with students }\end{array}$ \\
\hline Social/relational & $\begin{array}{l}\text { - Development of the feeling of belonging } \\
\text { to a group of colleagues who wish to } \\
\text { improve themselves professionally } \\
\text { - Acquisition of further social/relational } \\
\text { knowledge regarding the relationships } \\
\text { with students and their families }\end{array}$ \\
\hline
\end{tabular}

\section{Conclusion}

One of the important results achieved by the TRIS project is that it is already offering a new perspective on how to deal with "extreme" educational needs like those of students who cannot attend lessons regularly (or at all).

Aside from the primary goal of the socioeducational inclusion of homebound students, these experiences offer the school and research worlds a unique context for generating new forms of schooling and teaching, which take advantage of the potential of the new technologies [17].

In this light let us consider Table 5, which compares the features of a "normal" type of teaching with those of inclusive education for homebound students.

The last point in the table is particularly interesting, since it is often just those problematic situations which act as a kind of Trojan horse for wider reflection on the introduction of NMTs into teaching [18][19].

Undoubtedly, the proposal even to partially reprogramme teaching activities in order to facilitate a remote student's normal school attendance always causes great upheaval in the class teaching board, even more so if this implies the introduction/ "intrusion" of technologies. This confusion is even more significant if we consider the disproportionate overall effort required for managing what actually amounts to a single case.

These resistances can often be broken down if teachers can be made to take a positive view of what is certainly not a positive situation (especially for the disadvantaged student).

Table 5 - "Normal" teaching and teaching in the presence of problematic situations [18]

\begin{tabular}{|c|c|}
\hline a) "Normal" teaching & $\begin{array}{l}\text { b) Teaching in the presence } \\
\text { of problematic situations }\end{array}$ \\
\hline $\begin{array}{l}\text { School space and didactic } \\
\text { organisation inadequate for } \\
\text { the development of } \\
\text { pedagogical approaches } \\
\text { exploiting the potential of the } \\
\text { new technologies. }\end{array}$ & $\begin{array}{l}\text { The school space is anywhere } \\
\text { where study is possible (home, } \\
\text { hospital), preferably offering } \\
\text { the chance to do it in } \\
\text { collaboration with other, even } \\
\text { remote, students, and with } \\
\text { teachers' support even if they } \\
\text { are not always present. }\end{array}$ \\
\hline $\begin{array}{l}\text { Teachers hesitant in } \\
\text { considering teaching activity } \\
\text { which extends outside school } \\
\text { time. }\end{array}$ & $\begin{array}{l}\text { Most (sometimes all) teaching } \\
\text { activity is developed outside } \\
\text { the school spaces. }\end{array}$ \\
\hline $\begin{array}{l}\text { Teachers generally } \\
\text { unmotivated to change their } \\
\text { teaching style when they } \\
\text { perceive no real need for them } \\
\text { to do so. }\end{array}$ & $\begin{array}{l}\text { Teachers' strong motivation to } \\
\text { seek solutions which allow the } \\
\text { disadvantaged student to take } \\
\text { part in class lessons, helping } \\
\text { their study through } \\
\text { personalised paths potentiated } \\
\text { by technologies and making } \\
\text { them actively participate in } \\
\text { collaborative study activities } \\
\text { in class as well as in extra- } \\
\text { mural ones. }\end{array}$ \\
\hline $\begin{array}{l}\text { On the one hand, strong } \\
\text { perception of students' need } \\
\text { to acquire soft skills in using } \\
\text { technologies to enhance their } \\
\text { scholastic and lifetime } \\
\text { learning process. On the other } \\
\text { hand, since these skills are not } \\
\text { "assessable" for school credits } \\
\text { (except for ECDL - European } \\
\text { Computer Driving Licence } \\
\text { courses), technologies at } \\
\text { school are seen as } \\
\text { cumbersome and their use is } \\
\text { often a forced one, sometimes } \\
\text { not understood by students' } \\
\text { families (a teacher who uses } \\
\text { Facebook? Pure heresy!). }\end{array}$ & $\begin{array}{l}\text { Awareness that only through a } \\
\text { systematic and programmed } \\
\text { educational use of NMTs can } \\
\text { disadvantaged students enjoy } \\
\text { both equal opportunities in } \\
\text { following educational courses } \\
\text { and total autonomy also } \\
\text { thereafter in tackling their } \\
\text { lifetime knowledge needs. It } \\
\text { does not matter that these } \\
\text { skills are not recognised in } \\
\text { scholastic assessment. It is a } \\
\text { non-problem, since those skills } \\
\text { are not an extra but a } \\
\text { fundamental. And their } \\
\text { fundamental nature is } \\
\text { recognised and requested by } \\
\text { students' families themselves. }\end{array}$ \\
\hline $\begin{array}{l}\text { The above circumstances lead } \\
\text { to great difficulty in involving } \\
\text { the whole of a class teaching } \\
\text { board in re-planning the } \\
\text { teaching process in order to } \\
\text { include NMTs. }\end{array}$ & $\begin{array}{l}\text { It is often precisely these } \\
\text { problematic situations which } \\
\text { convince even the most } \\
\text { sceptical teachers to give it a } \\
\text { go, and which thus unite the } \\
\text { various members of a class } \\
\text { teaching board. }\end{array}$ \\
\hline
\end{tabular}

That is to say, if it can be demonstrated to them that the management of that problematic situation may become an opportunity for acquiring knowledge and skills on the educational use of NMTs, which 
can then be extended to the whole class (and more generally to the whole school), also for other future purposes.

So, not only for solving a (hopefully occasional) emergency situation, but also for innovating and potentiating the learning/teaching process throughout the class/school.

In this sense, the situations tackled in the TRIS project, in which teachers', head teachers', parents' and classmates' interest in finding solutions to include disadvantaged learners are evident, are revealing themselves to be incubators of educational innovation for the whole class/school involved, fostering exemplary experimentations in the didactic use of NMTs which can be used as models also for "normal" teaching.

The body of individual experiences deriving from such "extreme" didactic needs has provided and continues to provide school and research worlds with useful material for reflecting on and experimenting new forms of teaching. We are talking about an "open" type of teaching which ignores the physical perimeter in which the class usually operates, while guaranteeing the same social and communicative dimension that must be allowed to develop within a class [16].

Studying these "extreme" experiences may undoubtedly help us to correctly dose moments of face-to-face interaction with moments of individual and/or collaborative study potentiated by technologymediated interaction, also in a so-called "normal" teaching situation. It also helps us understand what role and functions a teacher must perform in order to successfully "oil" the new "learning mechanisms" which are increasingly centred on students' active role (learning by doing), as well as on the individual and informed use of the HLS which can be created with the technologies available to them on a day-today basis.

In other words, a teaching/learning situation which by force of circumstance is developed in noncircumscribed spaces may act as an example and a guide for the enrichment of the everyday life of a school that is still firmly anchored to schemes and practices which increasingly clash with students' expectations and the need for innovation [20].

\section{References}

[1] HOPE - Hospital Organisation of Pedagogues in Europe, The Rights and Educational Needs of Sick Children and Adolescents, HOPE Charter adopted by General Assembly of HOPE in Barcelona 20th May 2000. [2] R.M. Taylor, F. Gibson, and L.S. Franck, "The experience of living with a chronic illness during adolescence: a critical review of the literature", Journal of Clinical Nursing, 17, pp. 3083-3091, 2008.

[3] A. Jones, "A teacher's perspective of interacting with long-term absent students through digital communications technologies", in N. Reynolds and M. Turcsanyi-Szabo (eds.) Key competencies in the knowledge society, Springer, Berlin, 2010, pp. 187-192.

[4] K. Covey, "Utilizing Technology to Enhance the Educational and Social Experiences Designed for Homebound and In-Home Learners", in G. Trentin and V. Benigno (eds.), Network Technology and Homebound Inclusive Education, Nova Science Publishers Inc., Hauppauge, NY., 2013, pp. 1-14.

[5] J. Scott,, and S. Pardieck, "Technology Assisted Homebound Instruction: A Conceptual Framework", in G. Trentin and V. Benigno (eds.), Network Technology and Homebound Inclusive Education, Nova Science Publishers Inc., Hauppauge, NY., 2013, pp. 15-40.

[6] P. Patterson, and L. Tullis, "Guidelines for providing homebound instruction to students with disabilities", Preventing School Failure, 51, pp. 29-33, 2007, http://www.brainline.org/downloads/PDFs/Guidelines $\% 20$ for\%20Providing\%20Homebound\%20Instructions.pdf (Access Date: December 24, 2013).

[7] K. Wilkie, and A. Jones, "School ties: Keeping students with chronic illness connected to their school learning communities", in D. Benzie, K.W. Lai and C. Reffray (eds.), Proceedings of the New Developments in ICT and Education Conference. Amiens: International Federation for Information Processing, 2010.

[8] G. Trentin, V. Benigno, and M. Repetto, "The WISE Project and the Support for Social/Educational Inclusion", in G. Trentin and V. Benigno (eds.), Network Technology and Homebound Inclusive Education, Nova Science Publishers Inc., Hauppauge, NY., 2013, pp. 123-139.

[9] D.I. Fels, J.K. Waalen, S. Zhai, and P.T Weiss, "Telepresence under exceptional circumstances: enriching the connection to school for sick children", in Proceedings of Interact, 8th IFIP Conference on Human-Computer Interaction, Tokyo, Japan, July 9-13, 2001, pp. 617-624, http://www.ryerson.ca/pebbles/publications/fu193v6.pdf (Access Date: 15 March December, 2014).

[10] A. De Souza and Silva, "From Cyber to Hybrid: Mobile Technologies as Interfaces of Hybrid Spaces", Space and Culture, 9(3), pp. 261-278, 2006.

[11] G. Trentin, "Orientating Pedagogy towards Hybrid Spaces", in R.K. Atkinson (ed.), Progress in Education, Volume 35 (cap. 7), Nova Science Publishers Inc., Hauppauge, NY, 2015 (printing)

[12] O. Bray, "Using 1:1 to Unlock Learning: helping you move towards powerful and engaging 1:1 Learning, Teaching and Assessment scenarios", Microsoft Education, 2013, http://www.slideshare.net/Microsofteduk/ using-11-to-unlock-learning/ (Access Date: 13 December 2014).

[13] G. Trentin, V. Benigno, G. Caruso, F. Ravicchio, and M. Repetto, "Hybrid Learning Spaces for the socioeducational inclusion of homebound students", in C.A. Shoniregun and G.A. Akmayeva (eds.), Proceedings of IICE 2015, Ireland International Conference on Education, Dublin, Ireland, April 20-22, 2015, pp. 322327, Infonomics Society.

[14] P. Samsonov, and S. Harris, "Connecting HomeBound Students to Their Classrooms Using Technology", in G. Trentin and V. Benigno (eds.), Network Technology and Homebound Inclusive Education, Nova Science Publishers Inc., Hauppauge, NY, 2013, pp. 179-187.

[15] Alberta Education, Bring Your Own Device: A Guide for Schools, Alberta Education, School Technology Branch, 2012, http://education.alberta.ca/media/6749210/ 
byod\%20guide\%20revised\%202012-09-05.pdf (Access Date: May 03, 2014).

[16] L.Zimmerman, and A. Trekles Milligan, "Perspectives on communicating with the net generation", Innovate, 4(2), (2007),

http://www.innovateonline.info/index.php?view=article\&i $\mathrm{d}=338$ (Access Date: June 08, 2010).

[17] V. Benigno, G. Caruso, F. Ravicchio, M. Repetto, and G. Trentin, "Do BYOD (Bring Your Own Device) approach support inclusive virtual classrooms?", in Proceedings of ICERI14, 7th International Conference of Education, Research and Innovation, Seville, Spain, 2014.

[18] G. Trentin, "Approaching hospital-bound/homebound special education as an opportunity for innovation in teaching", Educational Technology, 54(1), pp. 26-30, 2014.

[19] D. Mitchel, "Inclusive Education", in D. Mitchel (ed.), Education that fits: Review of international trends in the education of students with special educational needs, Education Counts Publications, Chapter 11, 2010, http://www.educationcounts.govt.nz/publications/special_e ducation/education-that-fits-review-of-international-trendsin-the-education-of-students-with-special-educationalneeds/chapter-eleven-inclusive-education (Access Date: 11 November, 2013).

[20] C.A. Norris, and E. Soloway, "The opportunity to change education is, literally, at hand", Educational Technology, Special Issue on "Educational Technology in Europe", 52(2), pp. 60-63, 2012. 